than rural crimes. However, they connected female crime with peasant crime. In this way, according to Kowalsky, "social class and gender became markers of urban and rural, and thus of progress and backwardness." (118) Her case study of infanticide underscores this point. Soviet criminologists tended to accept prerevolutionary views about infanticide, believing it to be a sign of cultural backwardness. It was thought the crime was committed by single women out of shame or fear. Bolshevik social and legal policies that allowed abortions and provide financial support for single mothers were supposed to eliminate the reasons behind infanticide. So when infanticide rates continued to rise in the 1920s, criminologists scrambled to explain the situation. For instance, a sudden upsurge in the number of urban infanticide cases was linked to the migration of peasant women to the cities, because it was assumed they brought their "backwardness" with them. "By incorporating physiological factors into their explanations of infanticide," Kowalsky writes, "criminologists highlighted both the "naturalness' of the crime and the fundamental 'primitiveness' of women." She goes on to argue that, "In so doing, they unconsciously cast doubt on the ability of the socialist project to eliminate conditions that contributed to criminal activity, implying that women's crime was natural, rooted in biology, and thus immutable." (165-66)

In sum, this well-written and convincingly argued book will appeal to a number of audiences. By stressing Russia's connection to intellectual trends in Europe, Deviant Women, offers new insights to any Europeanist interested in criminology as well as intellectual and cultural history more generally. For Russian specialists, the book provides further evidence of the deep continuities that existed between the late imperial and early Soviet eras. It also raises disturbing questions about Soviet policies vis-à-vis women and sheds new light on Bolshevik efforts to transform society in the 1920s.

Alison Rowley

Concordia University

\title{
Thomas Wheatland, The Frankfurt School in Exile (Minneapolis, Minnesota: University of Minnesota Press, 2009).
}

Since Martin Jay, Rolf Wiggershaus, and Douglas Kellner's classic accounts, there have been few full-length historical accounts of the famed German-Jewish émigrés known collectively as the Frankfurt School. Given such a strong pedigree, the first thing that comes to mind as one sets out to read Thomas Wheatland's new book The Frankfurt School in Exile is what is left to say? Wheatland quickly takes up this concern in his introduction where he makes the claim that many of the traditional accounts of the Institut für Sozialforschung (Institute for Social Research) and their period of exile in the United States fail to adequately explore 
the cross pollination that took place between the "Horkheimer Circle" and North American intellectuals. It is precisely this history that the first section of Wheatland's book, "Critical Theory and Morningside Heights", sets its sights on.

Much of the history of the "Horkheimer Circle" unearthed by Wheatland in the first section focuses on the Institute for Social Research and their uneasy relationship with Columbia University as well as their falling out with one of its original members, Eric Fromm. Perhaps one of the most insightful themes developed here was Wheatland's discussion on how the Institute (largely through the quasi liaison efforts of Julian Gumperz and Eric Fromm) made their cutting edge social psychological research on fascism in Europe attractive to the empirical research agenda that was beginning to take shape in the fledgling department of sociology at Columbia. What is also brought to light in the first section of Wheatland's book is an emphasis on how the Institute suffered from the affects of institutional anti-Semitism at Columbia. In discussing the anti-Semitic sentiments that threatened the Frankfurt School's tenuous situation at Columbia, Wheatland points out to his readers that the émigrés were stuck between two serious obstacles: "The first was the pervasive anti-Semitism on Morningside Heights. An undisclosed quota system limited the amount of Jewish faculty members" (89). The second barrier to establishing a more permanent status for the Institute at Columbia Wheatland identifies was a civil war that was taking place amongst the faculty in Columbia's sociology department between advocates of empirical approaches to social scientific research and proponents of theoretical inquiry. Within this contentious and sometimes hostile context, Wheatland's ability to carefully weave the history of the Institute's ambiguous positionality while at Columbia within a larger philosophical and political environment is indeed one of the strongest aspects of his history of the early years of the "Horkheimer Circle" on Morningside Heights.

In what may be the best chapter of Wheatland's book, "John Dewey's Pit Bull: Sidney Hook and the Confrontation between Pragmatism and Critical Theory" (Ch. 3), a fascinating and previously neglected facet of Frankfurt School history is brought to light. While the sour relationship between American Pragmatism and Critical Theory is well known, as both Herbert Marcuse and Max Horkheimer wrote highly polemical critiques that focused on pragmatism's epistemology and theory of valuation (as did Dewey and Hook on Critical Theory's dialectical method) what has not been widely discussed are the interactions between Frankfurt School members and pragmatists while the group was in exile in New York. Part of the reason that Wheatland's research on the relationship between Critical Theory and Pragmatism is unique comes from the thrust of his thesis which suggests that the differences between the schools of thought suffered greatly from the effects of exaggeration. What was overshadowed in the meetings and debates between the two philosophical camps, Wheatland rightly notes, were larger shared concerns such as the rehabilitation of science for human emancipation, disdain for industrial society, and the loss of community in an increasingly standard- 
ized context for example. Indeed, as I have argued elsewhere, Marcuse's critique of pragmatism largely ignores how Dewey's political epistemology which looks to modern science as a methodological guide, is also situated within his theory of participatory democracy. This aspect of Dewey's work is never taken up in any of the attacks levelled by Frankfurt School Theorists. What Wheatland's analysis of the history of relations and writings between Sidney Hook and Critical Theorists thus accurately depicts is a larger pattern of speaking past each other that resulted in missing shared articulations that might have helped develop both group's evolving theories of late industrial society and culture as well as modes of political praxis. Wheatland indeed hits the mark when he says "at the very core of the debate between Sidney Hook and the Frankfurt School were two competing epistemological methodologies - scientific reason and critical reason. Ironically, each side made the same claim about the other-that the methodology formulated by the opponent represented a revival of metaphysics - and it was this accusation of metaphysical thinking that fed the bitterness and led to the circularity of the discussions" (135).

Where Wheatland's book falls short, however, is in his attempt to reinterpret the legacy of Herbert Marcuse from the recycle bin of history. In the final two chapters of Wheatland's book he spends a considerable amount of time making the argument that Marcuse's legacy as "guru" of the New Left was largely a result of media concoctions and the romanticizing of Marcuse by intellectuals working in the critical theory tradition after his death. While Wheatland is surely correct in pointing out that Marcuse "recognized the significance of the Movement and the events he was witnessing, and he sought to counsel the New Left as it grew and tried to articulate a new agenda for the late 1960's" he is not accurate in saying that "the New Left meant more to him than he meant to the New Left" (334). In attempting to reverse the polarity of power between the New Left and Marcuse, Wheatland in effect has repeated precisely what he claims the over exaggerated influence Marcuse had on the New Left has done to his legacy: imprisonment in the nostalgia of the 60's. If Wheatland's revised history of Marcuse's effect on the New Left emphasizes the true relation to be that of a student instead of a teacher, then what is lost is the deeper picture of Marcuse who was at once a teacher and student, a dialectician who absorbed as well as negated impulses of change and counterrevolt.

Despite the missteps associated with his analysis of Marcuse, Wheatland's history of the Frankfurt School in exile is, in final analysis, a valuable contribution to the literature. Those familiar with or new to the Critical Theory tradition and its origins should find something here to stimulate fresh perspectives and more developed understandings. In this regard, Wheatland's book has found something that was left to say. 